\title{
津波の初期波形よる係留船舶の動摇への影響について
}

\author{
榊原 繁樹 $*$ 久保 雅義 ${ }^{* *} \cdot$ 小林 英一**・越村 俊一***

\section{Dynamic Behavior of Moored Ship Motions induced by Initial Attack of Large Scaled Tsunami}

\author{
Shigeki SAKAKIBARA, Masayoshi KUBO, Eiichi KOBAYASHI and Shunichi
}

KOSHIMURA

\section{1. 粕言}

東海地震や東南海地震・南海地震の発生に伴い各 地港湾に大きな津波が来襲することが知られるよう になってきている(1)。一般に津波は地震による海底 の隆起で起こることから、緩やかな水位の上昇と下 降であると捉えられている。このことから係留船舶 も緩やかな上下運動を生じるのみと考えられている。 しかし津波には数分から 1 分程度の成分波が含まれ ていることから、係留船舶の長周期運動と共振する 可能性がある。また津波の流速は数 $\mathrm{m} / \mathrm{s}$ 程度で通 常の港内で発生する潮流に比べて大きく、大きな抗 力が係留船舶に作用する可能性もある。特に津波来 襲初期の水位上昇時において、両者の効果が相乗的 に作用して係留船舶に自由振動を誘発させるなど大 きな船体動摇を発生させる可能性がある(2)。

そこで本研究では津波の初期波形による係留船舶 の動摇への影響について動摇シミュレーションを用 いて検討した。
\end{abstract}

Abstract

Recently, it has been announced as a warning that the Tokai, Nankai and Tounankai earthquakes will be anticipated to surely occur within next 30 years. These earthquakes involve large scaled tsunami. When the tsunami attacks ships moored inside harbor basin, the motions might attain large movements that exceed the safe mooring conditions due to the surface elevation, the currents and a resonance effect with natural periods of sway or surge of the moored ships. In this paper, we propose a numerical simulation procedure of moored ship motions due to tsunami and investigate the effects on ship motions induced by the initial attack of the large scaled tsunami. Keywords : Tsunami, Long-period moored ship motions, Simulation method, Mooring system キーワード：津波，長周期船体運動，動摇シミュレーション，係留システム

\section{2. 洒波による係留船舶の耐摆解析}

\section{1 津波の水位変動およひ流速の設定}

まず対象港湾および対象船舶の係留バース周辺に おける津波の水位変動と流速を別途数值計算等によ り算出する(3)。そして当該バース位置における水位 変動と流速を設定する。Fig.1 は対象バースの船体 重心位置近傍における津波の水位変動と流速の時系 列計算結果である。

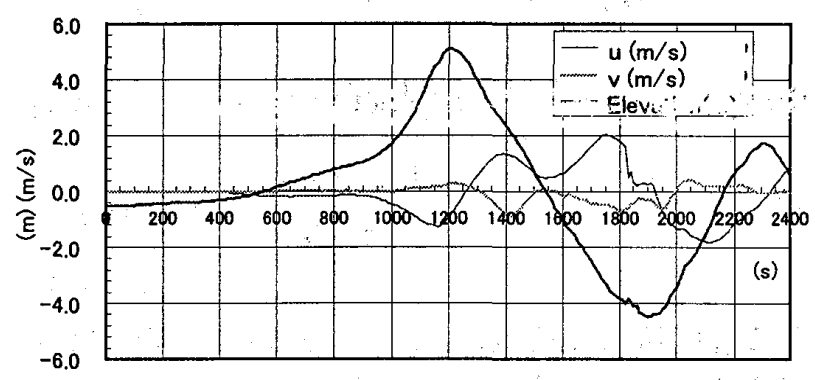

Fig. 1 Time Series of Surface Elevation and Currents of the Tsunami at the Target Berth

\footnotetext{
* 正会員 横浜ゴム株式会社 工業資材技術部 （干254-8601 神奈川県平塚市 2-1）

** 正会員 神戸大学 海事科学部 （T658-0022 神戸市東淎区深江南町 5-1-1）

*** 非会員 人と防災未来センター（T651-0073 神戸市中央区脇浜海岸通 1-5-2）
} 


\section{2 津波水位変動から成分波、速度ポテンシ ヤルおよび流速の設定}

一般に津波の数値計算では、長波理論に基づき、 任意地点における水位変動と流速が算出される。一 方船体に作用する波浪強制力や流れによる流圧力は 船体重心位置（座標原点）における速度ポテンシャ ルが与えられると求められる。震源地から広範囲な 計算領域を扱う津波計算と同時に、厳密に、港湾に おける係留船舶の運動を求めることは計算メッシュ の大きさなどの問題から現実的には困難である。そ こで両者を実用的に連結させる方法として、津波計 算から算出された水位変動を用いて次の手順で速度 ポテンシャルおよび流速を与える。

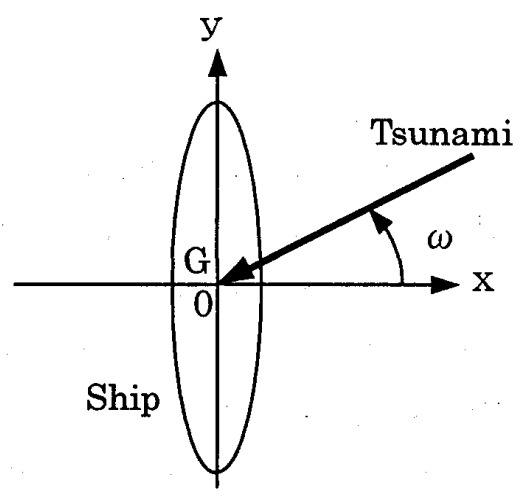

Fig. 2 Coordinate System for Velocity Potentials derived from Surface Elevation of Tsunami

Fig.2 に示すように静止時の船体重心回りの座標 系において入射角 $\omega$ で津波が進入する場合を考える。 このとき津波の水位変動とこれによる速度ポテンシ ヤルは式(1)のように表されるものとする。

$$
\begin{gathered}
\varsigma(x, y, t)=-\frac{1}{g} \frac{\partial \Phi}{\partial t} \quad \text { at } \mathrm{z}=0 \\
=-i \zeta_{0} \cdot \exp [i k(x \cos \omega+y \sin \omega)+i \sigma t] \\
\Phi(x, y, z, t)=\frac{g \zeta_{0}}{\sigma} \cdot \exp [i k(x \cos \omega+y \sin \omega)] \\
\cdot \frac{\cosh k(z+h)}{\cosh k h} \cdot \exp (i \sigma) .
\end{gathered}
$$

ここに $\mathrm{g}$ は重力加速度、 $\zeta_{0}, \sigma, \mathrm{k}$ は津波の振幅、 角周波数および波数、 $\mathrm{h}$ は水深、 $\mathrm{t}$ は時刻である。 また設定された速度ポテンシャルから船側方向（x 方向）および船首尾方向（y 方向）の水粒子速度は 次式で与えられる。

$$
u=\frac{\partial \Phi}{\partial x}
$$

$$
\begin{aligned}
& =\zeta_{0} \cdot \frac{\cosh k(z+h)}{\cosh k h} \cdot\left\{\frac{k g}{\sigma} \cos \omega\right\} \\
& \cdot \exp \left[i k(x \cos \omega+y \sin \omega)+i\left(\sigma t+\frac{\pi}{2}\right)\right], \\
& v=\frac{\partial \Phi}{\partial y} \\
& =\varsigma_{0} \cdot \frac{\cosh k(z+h)}{\cosh k h} \cdot\left\{\frac{k g}{\sigma} \sin \omega\right\} . \\
& \cdot \exp \left[i k(x \cos \omega+y \sin \omega)+i\left(\sigma t+\frac{\pi}{2}\right)\right]
\end{aligned}
$$

式(2)では $\mathrm{z}=0$ として水面上の值を用いる。

さらに津波の水位変動は不規則波として算出され ることから、式(3)のように FFT により成分波に分 解して成分波ごとに速度ポテンシャルおよび流速を 与える。ここに Neは成分波の個数である。

$$
\begin{aligned}
& \varsigma=\sum_{i=1}^{N e} \varsigma_{i}(x, y, t), \\
& \Phi=\sum_{i=1}^{N_{e}} \Phi_{i}(x, y, z, t), \\
& u=\sum_{i=1}^{N e} u_{i}(x, y, 0, t), \\
& v=\sum_{i=1}^{N_{\epsilon}} v_{i}(x, y, 0, t) .
\end{aligned}
$$

なお津波計算から算出される流速についても FFT を用いて成分波に分解し、成分波ごとにリサージュ 図形を作成して波向き (または流向) $\omega=\omega_{1}(\mathrm{i}=1,2, \ldots$, $\mathrm{Ne}$ )を設定する。

以上により、津波計算から求められる水位変動お よび流速データと船体に作用する波浪強制力や流圧 力算定に必要な速度ポテンシャルとが関連付けられ たことになる。

\section{3 波浪強制力および流圧力の算出}

式(3)で設定された速度ポテンシャルと流速を届 いて船体に作用する波浪強制力 $\mathrm{F}_{\mathrm{ex}}$ および流圧力 $\mathrm{F}_{\mathrm{c}}$ を求める。波浪強制力は式(3)の成分波ごとに別途 定常解析(4)により単位波振幅当りの波浪強制力 $\mathrm{f}^{\star}$ を 算出して、式(3)の波振幅と合わせて重ね合わせる ことで式(4)の不規則な波浪強制力を与える。

$$
F_{\text {ex }}=\sum S_{i} \cdot f_{i} \cdot \exp (i \sigma t)
$$

また流圧力については式(3)から流速の時系列 $\mathrm{u}=\mathrm{u}(\mathrm{u}, \mathrm{v}, \mathrm{t})$ を作成して式(5)のように与える。 


$$
F_{\mathrm{c}}=\frac{1}{2} \cdot \rho \cdot C \cdot A \cdot \mathbf{u}^{2}
$$

ここに $\rho$ は流体密度、C は抗力係数、A は受圧面積 である。

\section{4 係留船舶の時系列解析}

津波の初期波形による係留船舶の動摇解析は、従 来の岸壁係留船舶の解析(5) (6) と同様に式(6)の運動方 程式を解くことで行うことができる。

$$
\sum_{i=1}^{6}\left\{M_{i j}+m_{i j}(\infty)\right\} \cdot \ddot{x}_{i}(t)+\sum_{i=1}^{6} \int_{-\infty}^{t} \dot{x}_{i}(\tau) \cdot L_{i j}(t-\tau) d \tau
$$$$
+\sum_{i=1}^{6}\left(C_{i j}+G_{i j}\right) \cdot x_{i}(t)=F_{j},(j=1,2, \ldots, 6)
$$

ここに $x_{i}(t)$ は船体動摇の変位または回転角、 $M_{\mathrm{ij}}$, は 船体の質量または慣性モーメント、 $\mathrm{m}_{\mathrm{ij}}(\infty)$ は不変付 加質量または不変付加慣性モーメント、 $\mathrm{L}_{\mathrm{ij}}$ はメモリ 一影響関数、 $\mathrm{C}_{\mathrm{ij}}$ は静的復原力係数、 $G_{i j}$ は係留力係 数、 $F_{1}$ は外力項である。津波による波浪強制力およ び流圧力は式(6)の外力項に付与される。また粘性 抵抗は適宜考慮する。

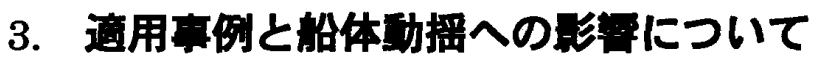 3.1 対象船舶}

津波の初期波形による係留船舶の動摇への影響を 調べるため、Fig.3 に示すシーバースに係留された $135,000 \mathrm{~m}^{3} \mathrm{LNG}$ 船を対象に検討した。当該 LNG 船 は $\phi 42 \mathrm{~mm}$ ワイヤーロープ（ナイロンテイルロー プ付き） 16 本と防舷材 4 基で係留される状況で、 係留索の初期張力は各索 10ton である。このとき 当該係留船舶の Sway および Surge 固有周期は $61 s$ と 136s である。座標系は船体重心位置を原点にと り、x 軸正方向が東方で $y$ 軸正方向が北方である。

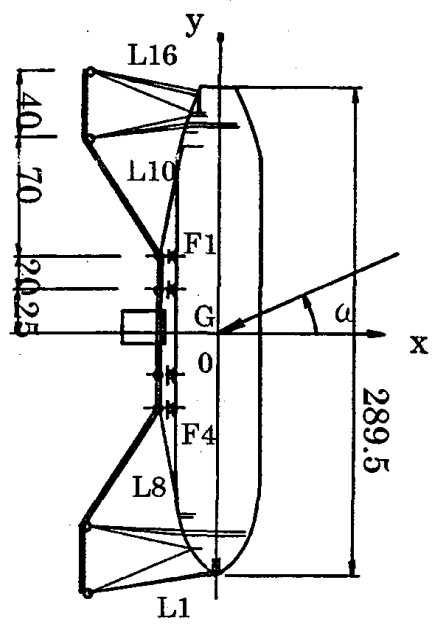

Fig. 3 Mooring Arrangement of $135,000 \mathrm{~m}^{3}$ LNG-tanker

\section{2 成分波の抽出方法と FFT による再現}

Fig.1 に示す津波の水位変動と流速の時系列が当 該船体重心位置（座標原点）におけるデータとする。 まず 2.2 に従い FFT により水位変動の成分波を抽 出する。成分波の総数および周波数分解能は、与え られた水位変動デー夕数 $N$ とサンプリング間隔 $\Delta t$ (ここでは $\mathrm{N}=512, \Delta \mathrm{t}=10 \mathrm{~s}$, 水位変動の原波形は約 5000s)により決まる。FFT により抽出した成分波 をすべて扱う場合、周波数分解能によっては、実波 形にない短周期波成分が強調され長周期波側の卓越 成分の再現が見づらくなる場合がある。そこで抽出 する閾值波振幅を設定して、船体に作用する波浪強 制力や流速算出に用いる成分波個数 $\mathrm{Ne}$ を限定した。

本研究では闒值波振幅を $5 \mathrm{~cm}, 1 \mathrm{~cm}$ とした。この とき抽出される成分波の個数はそれぞれ $\mathrm{Ne}=21,93$ となった。閾值波振幅を $5 \mathrm{~cm}$ とする場合、成分波 の周期惊 $T=5120 s \sim 160$ s に分布し、長周期船体運 動である Sway, Surge と共振する成分波は含まれ なかった。一方閥值波振幅を $1 \mathrm{~cm}$ とする場合、成 分波の周期は $T=5120 s \sim 45 s$ まで分布することに なり、Sway, Surge と共振する成分を含む抽出方法 となった。

波向きの設定は本来、成分波ごとにリサージュ図 形を作成して、それぞれに与える必要がある。本研 究ではまず津波の初期波形がどのように船体動摇へ 影響を与えるかを把握したいため、Fig.4 に示すよ うに簡易にすべての流速振幅データをプロットして 卓越波向きを設定した $(\omega=-30 \mathrm{deg})$ 。Fig.5 にこの ように設定した場合の FFT による津波の水位変動 および流速の再現波形を示す。水位変動に関しては よく再現されている。一方流速に関しては流速の絶 対值の大きさが過大に評価されている。これは波向 き設定の影響と考えられるが、水位変動に対する位 相関係はよく再現されている。

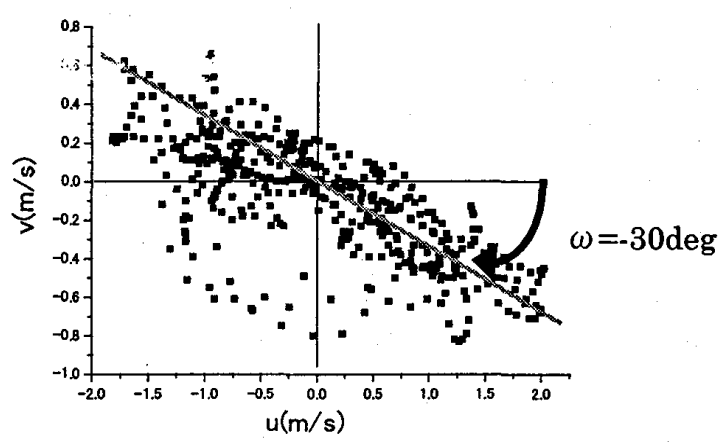

Fig. 4 Predominant Wave Direction due to the Current Data of the Tsunami 


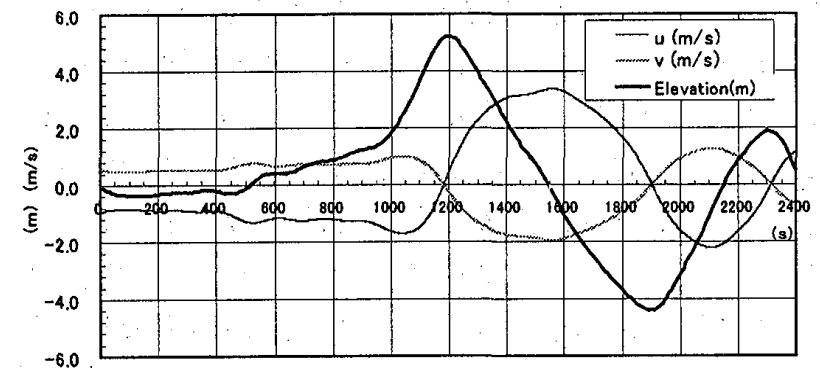

Fig. 5 Reproduction of Time Series of Surface Elevation and Currents of the Tsunami $(\mathrm{Ne}=21)$

\section{3 共振周期波を含まない場合（闑值波振幅 か $5 \mathrm{~cm}$ の場合)}

長周期船体運動との共振周期波を含む場合と含ま ない場合それぞれにつき、流圧力の考慮の有無によ る影響を調べる。なお Fig.5 に示す流速の再現計算 結果が Fig.1 に示す值に比べ過大に評価されていた ことから、流速の絶対值を合わせるように係数を乗 じて修正した。

(1) 流圧力を考慮しない場合

共振周期波を含まない場合で流圧力を考慮しない ときの船体動摇量の時系列計算結果を Fig.6(a)に示 す。Heaveに関しては津波の水位変動に一致した 動きとなった。Sway は津波到達前から最大潮位に 到るまでは岸壁側に変位して、そその後最低潮位にな るまでの間では沖側に変位している。引き続き潮位 の変動に対応した同様な動摇を生じているが、沖側 へ $2.5 \mathrm{~m}$ に及ぶ大きな動摇となった。Surge につい ても、津波到達前から顕著に自由振動を生じながら 船尾方向へシフトし、その後最低潮位になるまでの 間に逆に船首方向にシフトしている。引き続き同様 な潮位の変動に対応した動摇を生じているが、船首 尾にそれぞれ約 3m に及ぶ大きな移動が発生した。 Pitch, Roll, Yaw については微小な動摇を生じてい るのみであった。

Fig.6(b)に係留索 L1(bow line), L8(bow spring line), L10(stern spring line), L16(stern line)の張力および 防舷材 F1(stern side), F4(bow side)の反力時系列結 果を示す。Fig.6(a)の動摇量時系列結果に対応して、 津波到達前から係留索および防舷材に大きな荷重が 発生している。係留索の破断荷重は127tonである。 使用荷重を 42.3ton（安全率 3 として）とすると、 各索において使用荷重を超える張力が生じている。 防舷材については最大許容反力が 416ton (65\%圧縮 時)であることから、大きな圧縮変形が生じている ものの、許容範囲内であった。
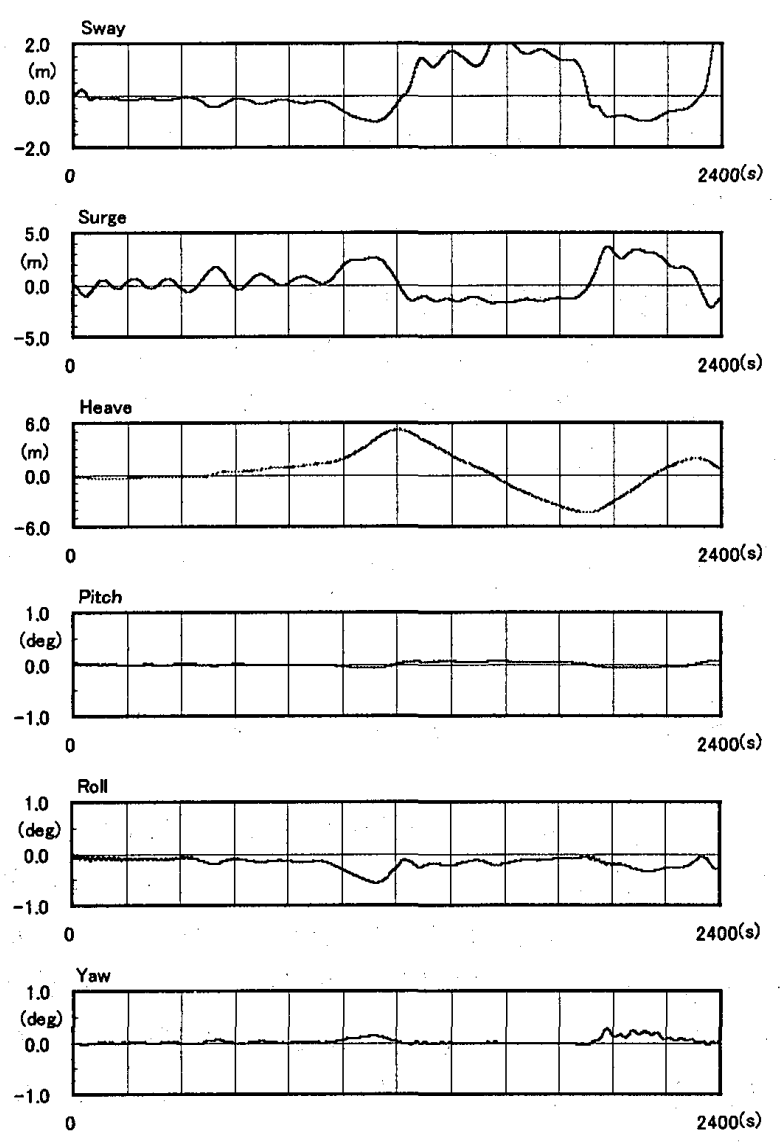

Fig. 6(a) Calculation Results of Moored Ship Motions due to Tsunami without Currents $(\mathrm{Ne}=21)$
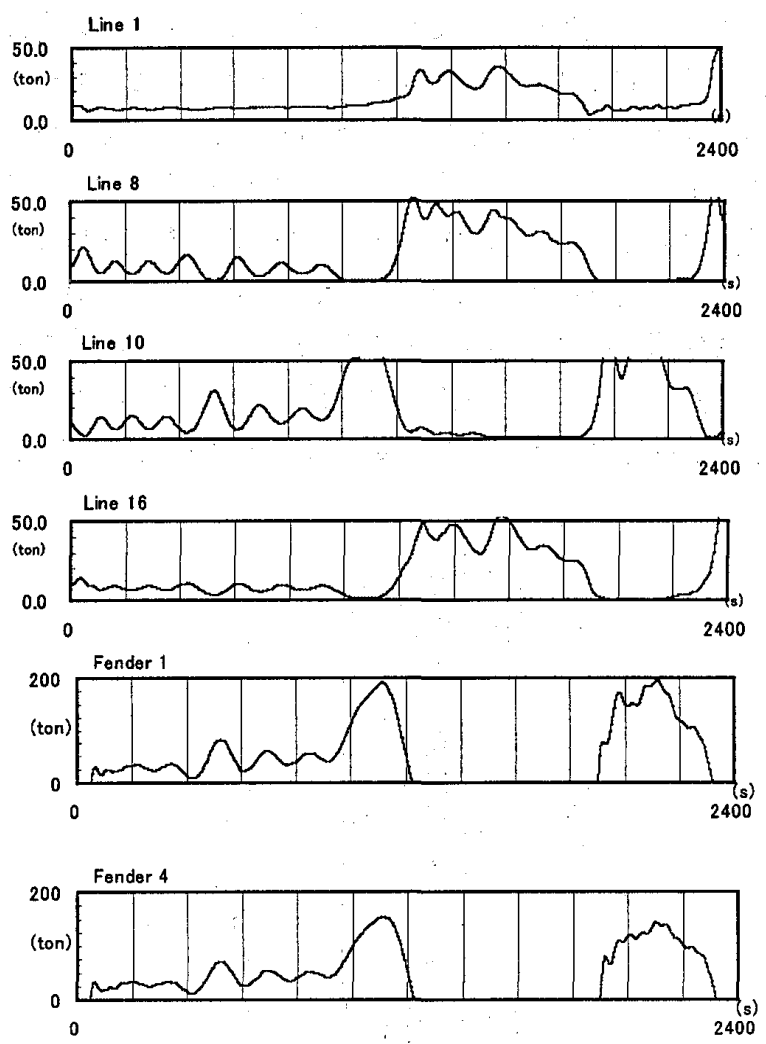

Fig. 6(b) Calculation Results of Mooring Loads due to Tsunami without Currents $(\mathrm{Ne}=21)$ 

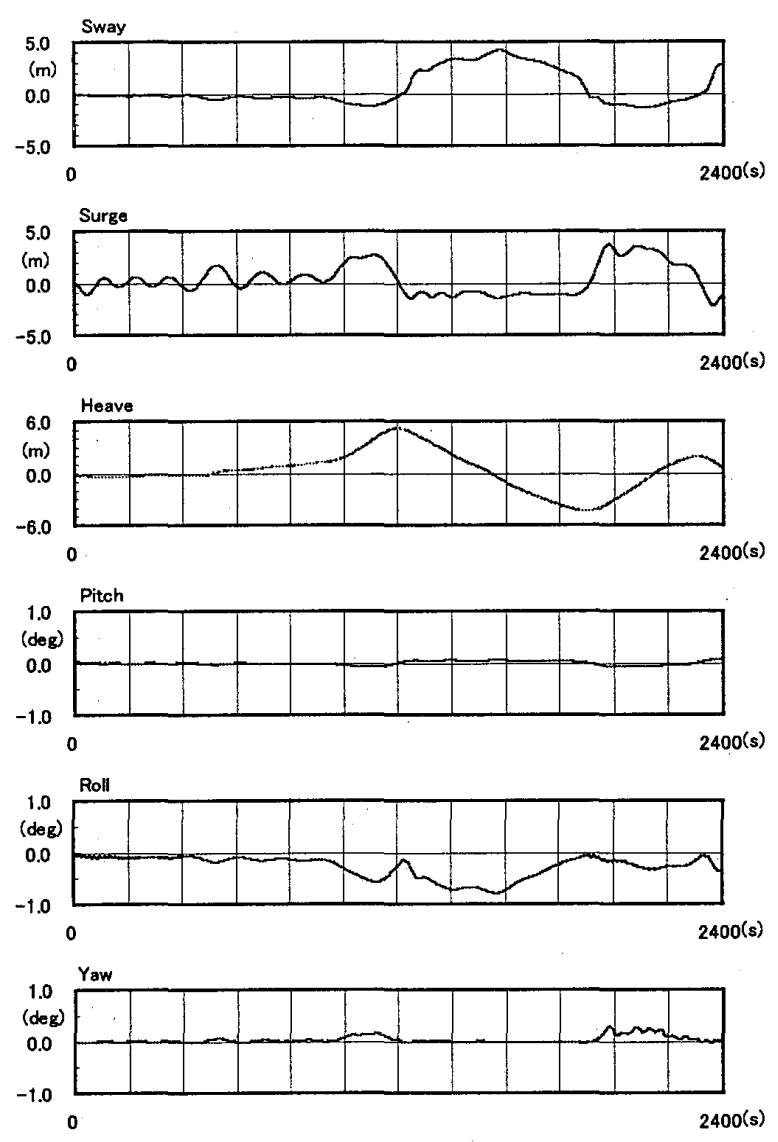

Fig. 7(a) Calculation Results of Moored Ship Motions due to Tsunami with Currents $(\mathrm{Ne}=21)$
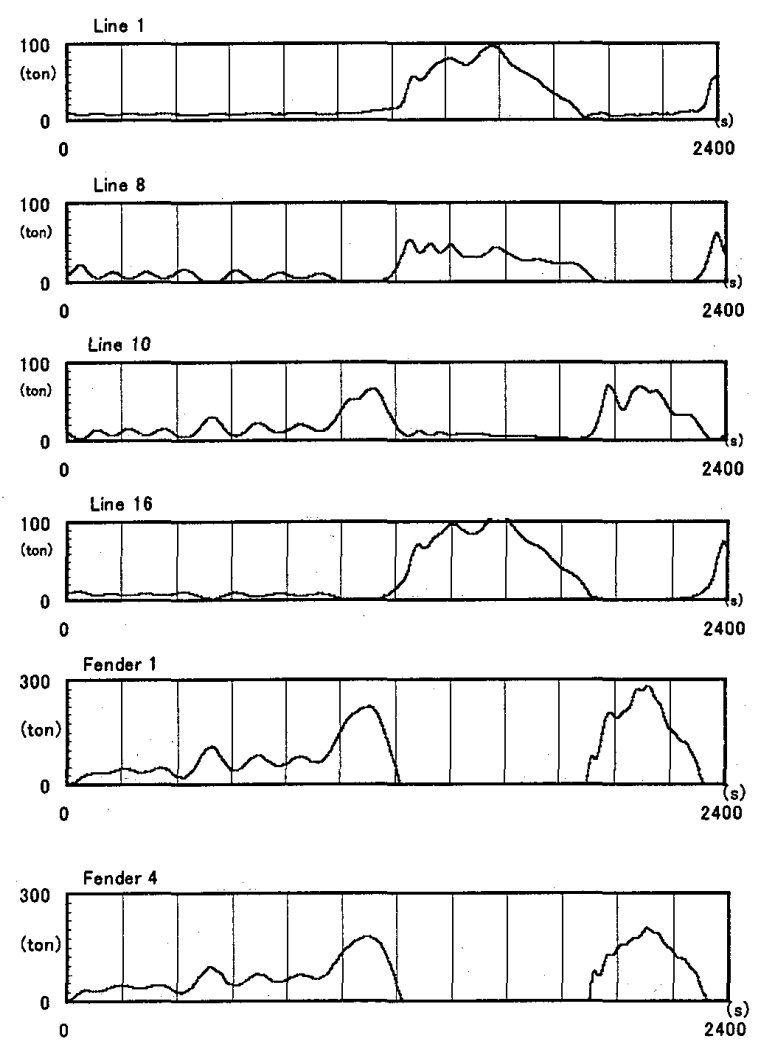

Fig. 7(b) Calculation Results of Mooring Loads due to Tsunami with Currents $(\mathrm{Ne}=21)$
（2）流圧力を考慮する場合

Fig.7(a)に共振周期波を含まない場合における流 圧力を考慮するときの船体動摇量の時系列計算結果 を示す。動摇特性としては Fig.6(a)の流圧力を考慮 しない場合とほぼ同じであるが、流圧力の影響によ り Sway の沖側への動摇量が 4.5m に及び、Sway との連成に伴い Roll にも大きな変位角が生じてい る。Fig.7(b)に係留力の計算結果を示すが、係留索 には 100ton を超える張力が生じ、係留索破断の危 険性が高い。また防舫材についても、許容範囲内で はあるが 300ton に至る反力が生じ、大きな圧縮変 形が生じている。当該係留システムの使用限界を超 える荷重が作用する結果となり、係留索の破断、本 船流出の危険性のある状況であることがわかる。

\section{4 共振周期波を含む場合（䦥值波振幅か $1 \mathrm{~cm}$ の場合)}

（1）流圧力を考慮しない場合

共振周期波を含む場合で流圧力を考慮しないとき の船体動摇量の時系列計算結果を Fig.8(a)に示す。

Fig.6(a)と比較すると、Heave と Pitch に関しては ほぼ一致した動きとなるが、Sway, Surge および Yaw においては共振に伴う動摇が水位変動に伴う 動摇に相乗して発生し、かなり異なる動摇特性とな ることがわかる。また Fig.8(b)には係留力の時系列 結果を示す。Fig.6(b)の係留力と比較すると、動摇 特性の変化に伴い係留特性も変化していることがわ かる。水位変動の緩やかな変化に合わせた張力変動 だけでなく、共振に伴う急激な張力変化が追加され 增加している。また防舷材においても Yaw の効果 が追加され、防舷材 F1 では最大反力を超える反力 が生じて過圧縮状態となっていることがわかる。

なお共振周期波を含まない場合と同様に、津波到 達前から Sway, Surge などに大きな動摇が発生す ると共に、これに伴い係留システムに過大な荷重が 作用していることがわかる。

（2）流圧力を考慮する場合

共振周期波を含む場合において流圧力を考慮する ときの船体動摇量の時系列計算結果を Fig.9(a)に示 す。Fig.7(a) と比較すると、共振に伴う動摇が相乗 的に発生してかなり異なる動摇特性となっているこ とがわかる。Fig.9(b)に係留索張力および防舷材を 示すが、津波による水位変動、Sway, Surge, Yaw における共振、さらには流圧力の効果が相乗的に係 留システムに作用し、係留索の破断や防舷材の破損 さらには本船流出や岸壁施設の損傷の可能性が高い 状況であることがわかる。 

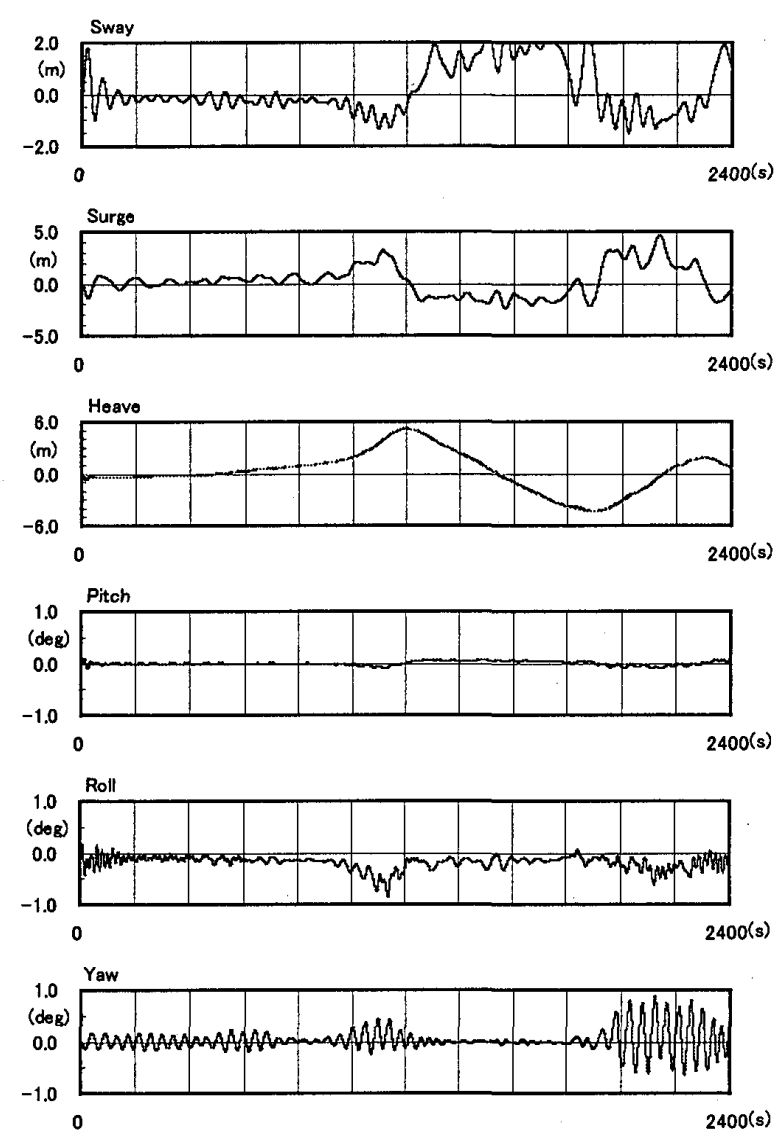

Fig. 8(a) Calculation Results of Moored Ship Motions due to Tsunami without Currents $(\mathrm{Ne}=93)$
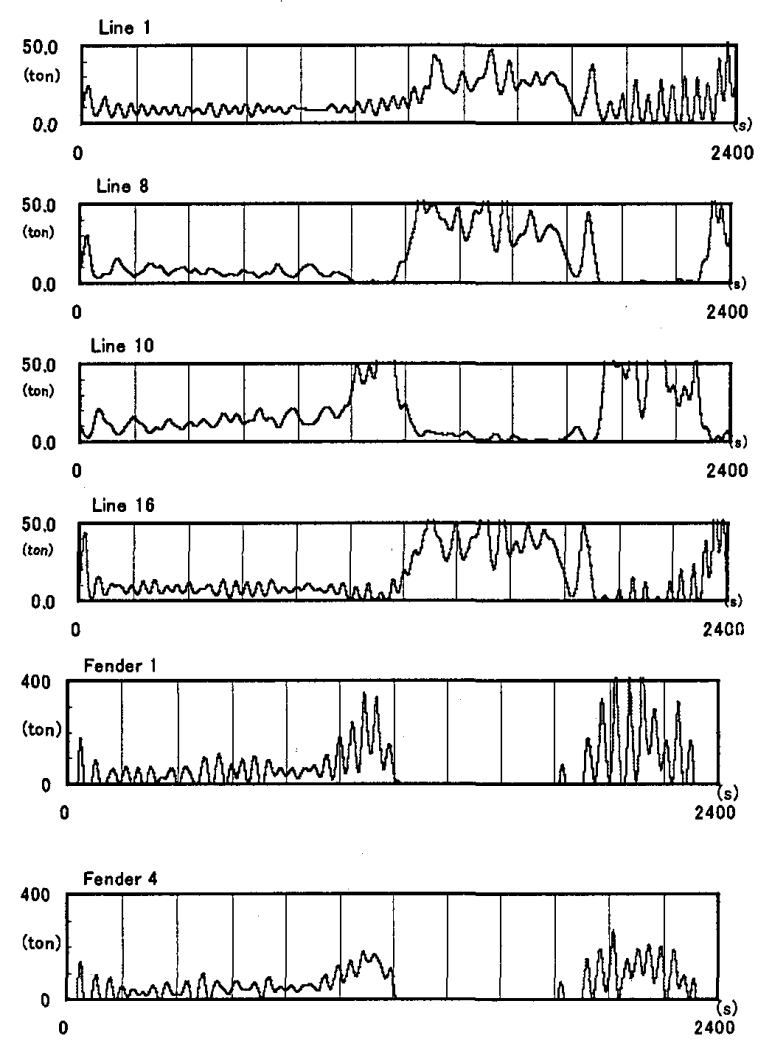

Fig. 8(b) Calculation Results of Mooring Loads due to Tsunami without Currents $(\mathrm{Ne}=93)$
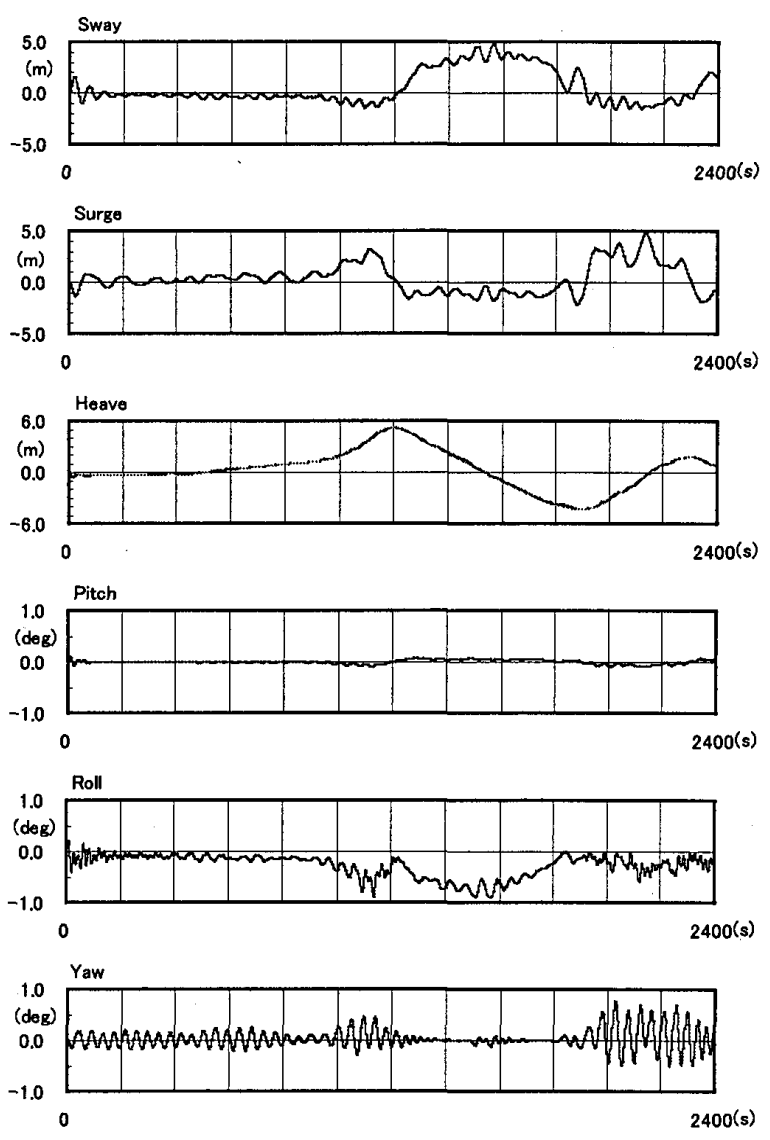

Fig. 9(a) Calculation Results of Moored Ship Motions due to Tsunami with Currents $(\mathrm{Ne}=93)$
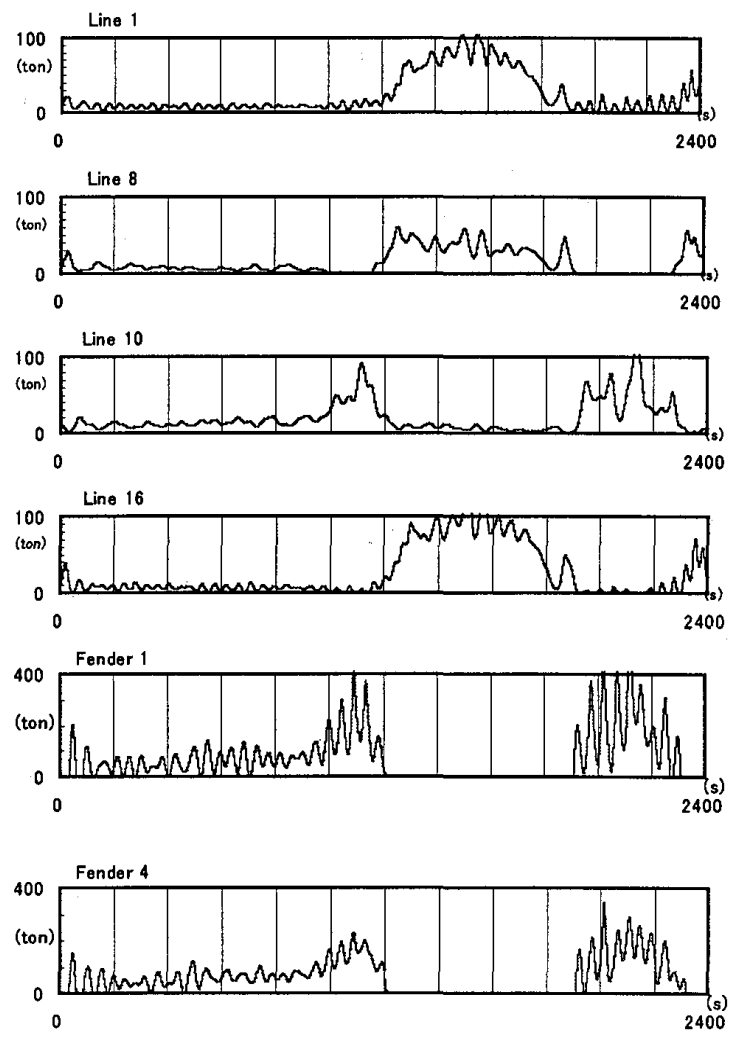

Fig. 9(b) Calculation Results of Mooring Loads due to Tsunami with Currents $(\mathrm{Ne}=93)$ 
なお Fig.8 および, Fig.9の Sway, Roll などの時系 列において、シミュレーション開始と同時に大きな 動摇が発生している。これは時系列解析で解が収束 せずに発散する現象ではなく（時系列解析における 時間ステップは $\Delta t=0.25$ として、最短波周期に対 して充分な時間刻みとしている)、設定した津波水 位変動に含まれる短周期波成分による動摇である。

\section{4. 桔語}

本研究では津波の初期波形による係留船舶の動摇 への影響を検討するために、津波による係留船舶の 動摇解析手順を示した。そして津波成分波の抽出方 法や流圧力考慮の有無による係留船舶の動摇量、係 留索張力および防舷材変形量などへの影響について 様々なケースを設定して動摇シミュレーションを用 いて検討した。得られた結論を要約すると次のよう になる。

(1)津波到達前から Sway, Surge などに大きな動摇 が発生し、これに伴い係留システムにも過大な 荷重が作用し始めることがわかった。

(2)津波の水位変動による波力だけでなく、津波に よる流圧力を合わせて考慮することで Sway, Surge などにさらに大きな動摇が発生することが わかった。

(3)津波到達時に Heave に最大值を生じるが、その 前後で Sway,Surge に大きな動摇が生じることが わかった。

(4)波の最下点で Heave に最小値を生じるが、その 直後から Sway,Surge に大きな動摇が生じること がわかった。

(5)津波のピークおよびボトム水位前後における大 きな Sway,Surge により係留索の破断や防舷材の 過圧縮の危険性のあることがわかった。

(6)津波の成分波分解においては Sway, Surge, Yaw といった長周期船体運動の固有周期を考慮して 設定する必要性がある。津波の緩やかな水位変 動だけでなく、津波に含まれる長周期波成分と の共振や流れによる自由振動により、当該運動 モードではさらに大きな動摇が誘発される。

今回は $135,000 \mathrm{~m}^{3} \mathrm{LNG}$ 船を例に検討したが、同 じ船種・船型においても津波に対するバース向きの 影響、載貨状態の影響、係留索の初期張力や防舷材 種類など倸留システムの影響などによっても船体動 摇特性は変化する。そこでさらに、船種・船型の違 いの影響や港内におけるバース配置の影響など、 様々な観点から津波の初期波形による係留船舶の動
摇への影響について今後研究を進めたいと考えてい る。また従来の津波計算と船体回りの速度ポテンシ ヤルを関連付けることで寒用的な津波による係留船 舶の動摇解析手法を提案したが、この理論的な根拠 や有効性などについて検討を加えたいと考えている。

近年、地震津波による被害や津波の特性に関する 研究がさかんに行われている(7)。本研究が津波作用 下、特に津波の来襲初期段階における係留船舶の動 摇特性評価や安全な係留システムの検討、さらには 港湾およびバースの防災に関する検討への一助とな れば幸いである。

\section{考文献}

（1）内閣府編 : 防災白書, 2004.

（2）久保雅義・榊原繁樹・小林英一・越村俊一：津 波が船舶及び港湾へ及ぼす影響に関する基礎的 研究，日本航海学会論文集，第 112 号, 2004（投 稿中）。

（3）越村俊一：津波の数值解析技術とその応用, 非 破壊検査, Vol.52, pp.344-348, 2003.

（4）椹木亨・久保雅義 : 荷役限界からみた港内静稳 度に関する研究,直線岸壁および Slip 内係留船 の運動特性,海岸工学論文集, 第 27 巻, pp.307$311,1980$.

（5）久保雅義・笹健児・白石悟・榊原繁樹 : 数値計 算手法が長周期波作用下における長周期船体動 摇へ及ぼす影響について, 海岸工学論文集, 第 44 巻, pp.236-240, 1997.

（6）久保雅義・榊原繁樹 : 湾水振動を考慮した港内 係留船舶の時系列解析, 日本航海学会論文集, 第 100 号, pp.121-130, 1999.

（7）富田孝史·河合弘泰・柿沼太郎: 平成 15 年 $(2003$ 年）十勝沖地震津波による被害と津波の特性, 港湾空港技術研究資料, No.1082, 2004.

\section{要聟店答}

\section{井関俊夫（東京海洋大学）:}

FFT による成分波抽出にォ河る陸岸からの反射 波はどのように考慮されているでしょうか。

\section{榊原繁樹 :}

今回の適用事例では洋上のシーバースに係留され た LNG 船を対象に検討したことと、Fig.4 から 波の主方向が比較的明確に与えられる条件であっ たことから反射波は考慮していません。対象船舶 が港内の岸壁前面に係留される場合や成分波ごと にリサージュ図形を作成して反射波の影響が顕著 にみられる場合は反射波を考慮する必要性がある 


\section{と考えます。}

寺田大介（株式会社エム・オー・マリンコンサル ティング） :

前後方向の減衰係数がシミュレーション結果に大 きく影響すると思いますがどのように与えられて いますか。

\section{榊原繁樹 :}

深江丸を使った自由振動実験や長周期波作用下に おける係留船舶の動摇に関する現地実験結果との 再現計算検討を参考にして、時系列解析内に考慮 しています。 